\title{
Modelonzekerheid en Waardering
}

Citation for published version (APA):

Pelsser, A. A. J. (2010). Modelonzekerheid en Waardering. Maastricht University. https://doi.org/10.26481/spe.20100924ap

Document status and date:

Published: 24/09/2010

DOI:

10.26481/spe.20100924ap

Document Version:

Publisher's PDF, also known as Version of record

\section{Please check the document version of this publication:}

- A submitted manuscript is the version of the article upon submission and before peer-review. There can be important differences between the submitted version and the official published version of record.

People interested in the research are advised to contact the author for the final version of the publication, or visit the DOI to the publisher's website.

- The final author version and the galley proof are versions of the publication after peer review.

- The final published version features the final layout of the paper including the volume, issue and page numbers.

Link to publication

\footnotetext{
General rights rights.

- You may freely distribute the URL identifying the publication in the public portal. please follow below link for the End User Agreement:

www.umlib.nl/taverne-license

Take down policy

If you believe that this document breaches copyright please contact us at:

repository@maastrichtuniversity.nl

providing details and we will investigate your claim.
}

Copyright and moral rights for the publications made accessible in the public portal are retained by the authors and/or other copyright owners and it is a condition of accessing publications that users recognise and abide by the legal requirements associated with these

- Users may download and print one copy of any publication from the public portal for the purpose of private study or research.

- You may not further distribute the material or use it for any profit-making activity or commercial gain

If the publication is distributed under the terms of Article $25 \mathrm{fa}$ of the Dutch Copyright Act, indicated by the "Taverne" license above, 


\section{Maastricht University}

\section{Prof.dr. Antoon Pelsser}

School of Business and Economics

\section{Modelonzekerheid en Waardering}

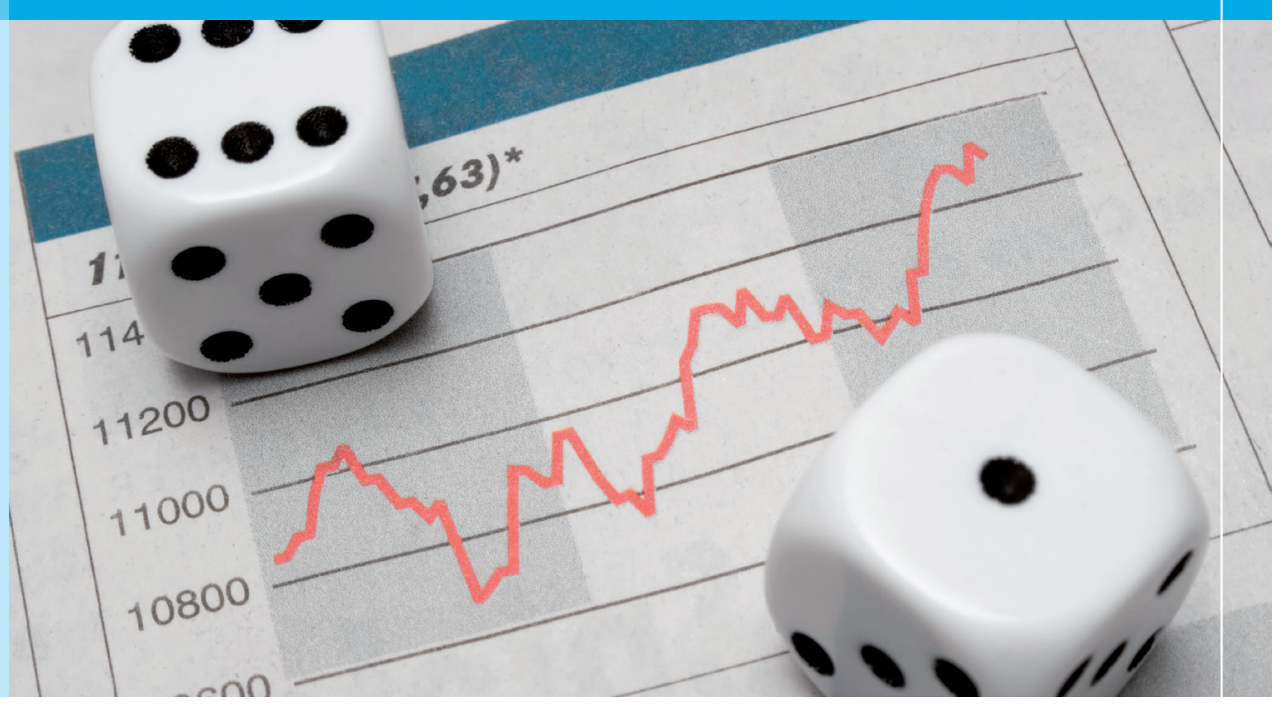


Modelonzekerheid

en

Waardering 


\section{Colofon}

Ontwerp omslag en print: Océ Business Services, Maastricht

ISBN: $978-90-5681-344-4$

NUR: 793

Alle rechten voorbehouden. Niets uit deze uitgave mag worden verveelvoudigd, opgeslagen in een geautomatiseerd gegevensbestand of openbaar gemaakt worden, zonder voorafgaande schriftelijke toestemming van de auteur of uitgever. 


\section{Modelonzekerheid}

\section{en}

\section{Waardering}

\section{Oratie}

In verkorte vorm uitgesproken bij de aanvaarding van het ambt van hoogleraar "Financiering en Actuariële Wetenschappen" aan de School of Business and Economics van de Universiteit Maastricht.

Op 24 september 2010

Door prof.dr. Antoon Pelsser 


\section{Modelonzekerheid}

Mijnheer de Rector Magnificus, geacht College van Decanen, geachte collega's, zeer gewaardeerde toehoorders, lieve familie.

\subsection{Kansmodel}

In deze rede zal het veelvuldig gaan over kansmodellen. Dit zijn modellen waar we onzekere gebeurtenissen mee beschrijven. Om u een gevoel te geven voor wat een kansmodel is, kijken we naar een voorbeeld: een dobbelsteen. Als we met een dobbelsteen gooien, dan is de uitkomst onzeker: we gooien ergens tussen de 1 en 6 "ogen". Als de dobbelsteen eerlijk is, dan is de kans op elke uitkomst gelijk, te weten $1 / 6$ ofwel $16.7 \%$ per kant. Het kansmodel voor een dobbelsteen is de wiskundige abstractie dat we 6 mogelijke uitkomsten hebben " 1 ", " 2 ",.., "6", elk met een kans van $1 / 6$. De intuï-

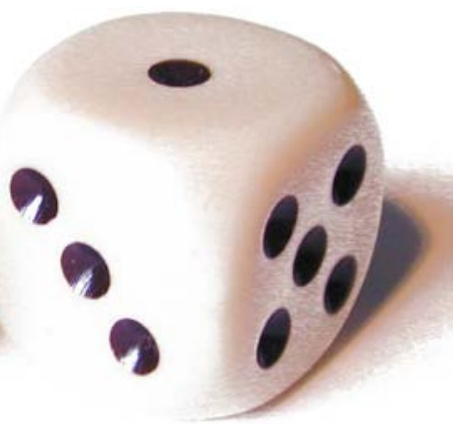
tieve interpretatie van het begrip "kans" is dat als we heel vaak met de dobbelsteen gooien (zeg 10.000 keer) en steeds opschrijven hoeveel ogen we gooien, dat dan elk van de zes uitkomsten ongeveer even vaak voorkomt (dus ongeveer 10.000 / $6=1667$ keer).

Stel nu dat $\mathrm{u}$ mee mag doen met een gokspelletje. $\mathrm{U}$ betaalt een inleg, en vervolgens gooien we met een dobbelsteen. Voor elk oog dat u gooit krijgt $u € 1$. Welk bedrag wilt $u$ inzetten? Als je heel vaak gooit, heb je een gelijke kans van $1 / 6$ op elk van de 6 uitkomsten. De verwachtingswaarde is daarom $1 / 6 *(1+2+3+4+5+6)=€ 3,50$. Dus, bij een 
eerlijke dobbelsteen, zou u ten hoogste een inleg van $€ 3,50$ moeten betalen, want bij deze inleg speel je op lange termijn net quitte.

\subsection{Modelonzekerheid}

Laten we nu een stap verder gaan. Stel nu dat we niet zeker zijn of de dobbelsteen waarmee het gokspel wordt gespeeld wel eerlijk is. We spelen bijvoorbeeld het gokspel via een website op internet. We hebben nu te maken met het begrip modelonzekerheid: we weten dat we een kansmodel moeten gebruiken, maar we zijn onzeker over de juiste kansen die we in het model moeten gebruiken. Is het nu verstandig om een inzet van $€ 3,50$ te betalen?

Het begrip modelonzekerheid kan als volgt gekarakteriseerd worden:

- We weten met zekerheid de "spreiding" van de uitkomsten. In ons geval, weten we zeker dat er een uitkomst tussen de 1 en de 6 ogen kan vallen.

- We zijn onzeker over de juiste kansen.

- Echter, we zijn wel in staat om boven- en ondergrenzen aan te geven. We tasten dus niet totaal in het duister over de kansen.

Als we terugkeren naar ons voorbeeld van de goksite, dan zou het bijvoorbeeld zo kunnen zijn dat we een aantal keren mogen proefgooien met de internet-dobbelsteen, om een indruk te krijgen van de kansverdeling. Hoe vaker we mogen proefgooien, hoe zekerder we kunnen zijn of de dobbelsteen eerlijk is. Maar $100 \%$ zekerheid kunnen we nooit bereiken. Het blijkt trouwens behoorlijk lastig te zijn om door middel van proefgooien vast te stellen of een dobbelsteen eerlijk is. Als we 2000(!) keer mogen proefgooien met een eerlijke dobbelsteen, dan kunnen we een de kansen begrenzen tussen de $15 \%$ en de $18.5 \%$. 


\subsection{Robuustheid}

Gegeven deze grenzen op de kansen, wat is nu een verstandig bedrag om als inleg te betalen? We gaan nu het begrip robuustheid introduceren. Als we robuust willen zijn, dan houden we rekening met het slechtst denkbare kansmodel binnen de gegeven grenzen, en proberen dan een zo goed mogelijke beslissing te nemen. Dit idee van robuustheid komt oorspronkelijk uit de technische wetenschappen. Stel dat je een regelsysteem voor een kerncentrale ontwerpt, dan wil je toch heel graag dat het regelsysteem een zo goed mogelijke beslissing neemt, zelfs als zich een combinatie van uitzonderlijk slechte omstandigheden voordoet.

\begin{tabular}{|r|r|r|r|r|r|r|}
\hline $\mathbf{6}$ & $\mathbf{5}$ & $\mathbf{4}$ & $\mathbf{3}$ & $\mathbf{2}$ & $\mathbf{1}$ Prijs \\
\hline $15.0 \%$ & $15.0 \%$ & $15.0 \%$ & $18.0 \%$ & $18.5 \%$ & $18.5 \%$ & 3.34 \\
\hline
\end{tabular}

\section{Figuur 1: Slechtste verdeling van kansen}

Wat is nu het slechtst denkbare model voor onze dobbelsteen? De uitbater van de website zal ongetwijfeld als doel hebben om zo veel mogelijk winst te maken. Dus hij zal proberen de uitbetalingen zo laag mogelijk te maken. Dat kan hij doen door de kans op "hoge ogen" zo laag mogelijk te maken, en de kans op "lage ogen" zo hoog mogelijk te maken. Hij kan echter niet onbeperkt rommelen met de kansen, de kansen moeten binnen de grenzen van $15 \%$ en $18.5 \%$ blijven, en de kansen moeten samen tot $100 \%$ optellen. Een beetje puzzelen laat al snel zien dat de slechtst denkbare verdeling van de kansen is zoals weergegeven in Figuur 1.

De hoge uitkomsten 6,5,4 hebben een kans van $15 \%$, de lage uitkomsten 1,2 hebben een kans van $18.5 \%$, en om de kansen tot 1 te laten optellen heeft de uitkomst 3 een kans van $18 \%$. Voor deze verdeling van kansen is de verwach- 
tingswaarde $€ 3,34$, en dat is lager dan de "eerlijke" verwachtingswaarde van $€ 3,50$.

Samenvattend, als u onzeker bent of de dobbelsteen eerlijk is, en $u$ weet dat de kansen ergens tussen de $15 \%$ en $18.5 \%$ liggen, dan is de "robuuste beslissing" om ten hoogste een inzet van $€ 3,34$ te willen betalen voor het internet gokspelletje.

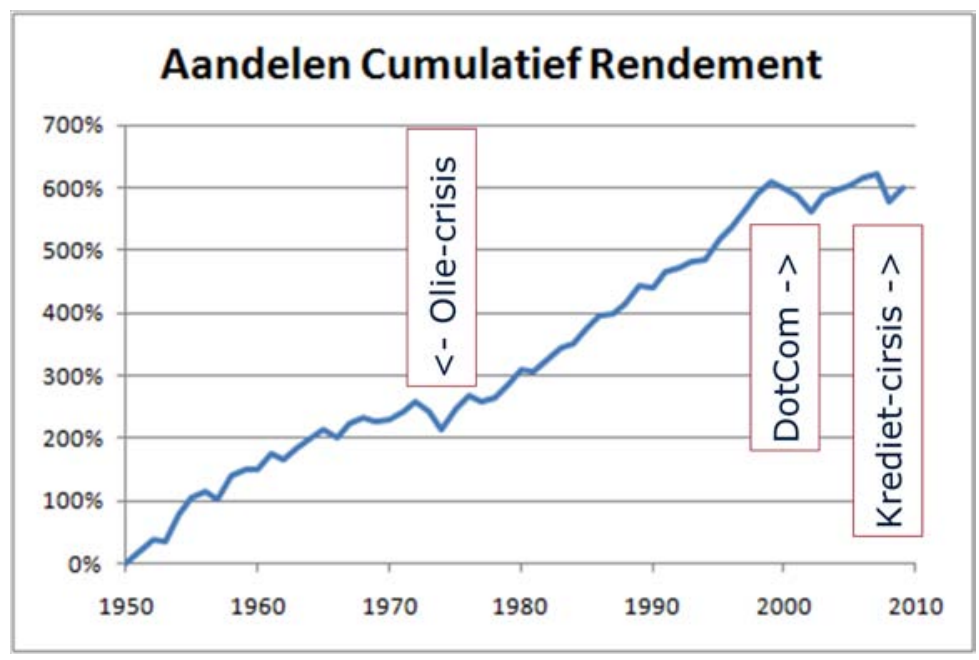

Figuur 2: Cumulatief Rendement op Aandelen

\subsection{Rendement op Aandelen}

We hebben nu genoeg spelletjes gespeeld. Laten we eens kijken naar voorbeelden van modelonzekerheid zoals we die in de economie tegenkomen.

In Figuur 2 hebben we het cumulatief beleggingsrendement op de Amerikaanse S\&P index weergegeven voor de periode van 1950 tot 2009. Als we in 1950 slechts 1 dollar hadden 
belegd in de S\&P index, dan zou die zijn aangegroeid tot 400 dollar in 2009. Dit komt overeen met een cumulatief beleggingsrendement van zo'n $600 \%$ in ongeveer 60 jaar tijd. En dat is dus een gemiddeld rendement van ongeveer $10 \%$ per jaar. Deze berekening lijkt zo klaar als een klontje. Toch hebben we hier ook te maken met modelonzekerheid. We zijn namelijk helemaal niet zo zeker over het gemiddelde beleggingsrendement.

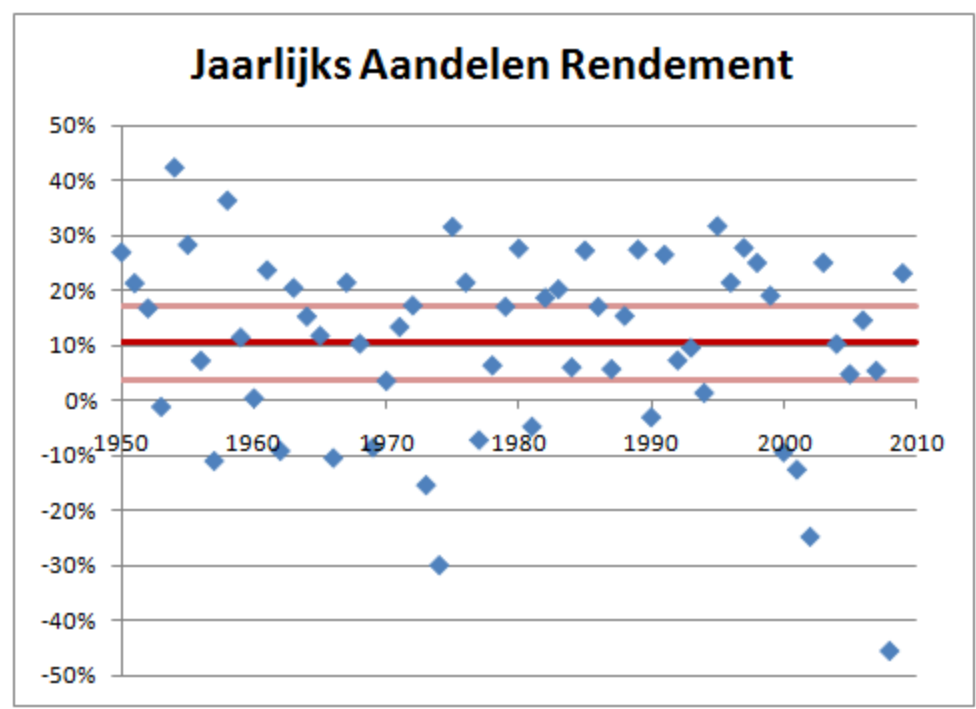

Figuur 3: Jaarlijks Beleggingsrendement

Om dit beter inzichtelijk te maken kijken we op een andere manier naar deze data. In Figuur 3 hebben we de jaarlijkse beleggingsrendementen van de S\&P index weergegeven. Het plaatje ziet er nu een stuk rommeliger uit. Wat we nu heel goed zien is de grote spreiding tussen de mogelijke rendementen. In goede jaren kun je rendementen van meer dan $30 \%$ behalen, maar in slechte jaren kun je meer dan $20 \%$ verliezen. 
Je zou nu kunnen zeggen dat we 59x hebben gegooid met de "beleggingsdobbelsteen". Op basis van deze 59 waarnemingen willen we bepalen wat het gemiddelde beleggingsrendement is. Dit gemiddelde rendement speelt een heel belangrijke rol bij beleggingsmodellen waar we beleggingsrendementen naar de toekomst projecteren. Als we het gemiddelde nemen van deze 59 waarnemingen vinden de waarde van $10.4 \%$ die we eerder ook al hadden gevonden. Dit is de dikke rode lijn in Figuur 3. Omdat de spreiding in de gerealiseerde rendementen zo groot is, is deze schatting van $10.4 \%$ niet erg nauwkeurig. Statistisch gezien is de fluctuatie in de uitkomsten zo groot, dat het werkelijke rendement ergens tussen de $\mathbf{1 7 . 2} \%$ en $3.7 \%$ zou kunnen liggen. Deze grenzen zijn weergegeven met de lichtrode lijnen.

\subsection{Projectie van Rendementen}

Verzekeringsmaatschappijen en pensioenfondsen maken veelvuldig gebruik van modellen bij het bepalen van hun beleggingsbeleid en het vaststellen van de hoogte van de premies. Omdat levensverzekeringen en pensioenproducten langlopende producten zijn, worden binnen deze modellen langjarige toekomstprojecties gemaakt. Projecties tot 50 jaar vooruit zijn bepaald geen uitzondering. Ook de toezichthouder verlang dit soort langjarige projecties om een inzicht te krijgen in de toekomstige ontwikkeling en financiële gezondheid van het fonds of de verzekeringsmaatschappij. Kortom, met maken van langjarige projecties is tegenwoordig "core business" voor actuarissen en risicomanagers.

Hoe kunnen we nu langjarige projecties maken voor aandelenrendementen? In principe komt dit neer op het doortrekken van "de trend" zoals weergegeven in Figuur 4. 


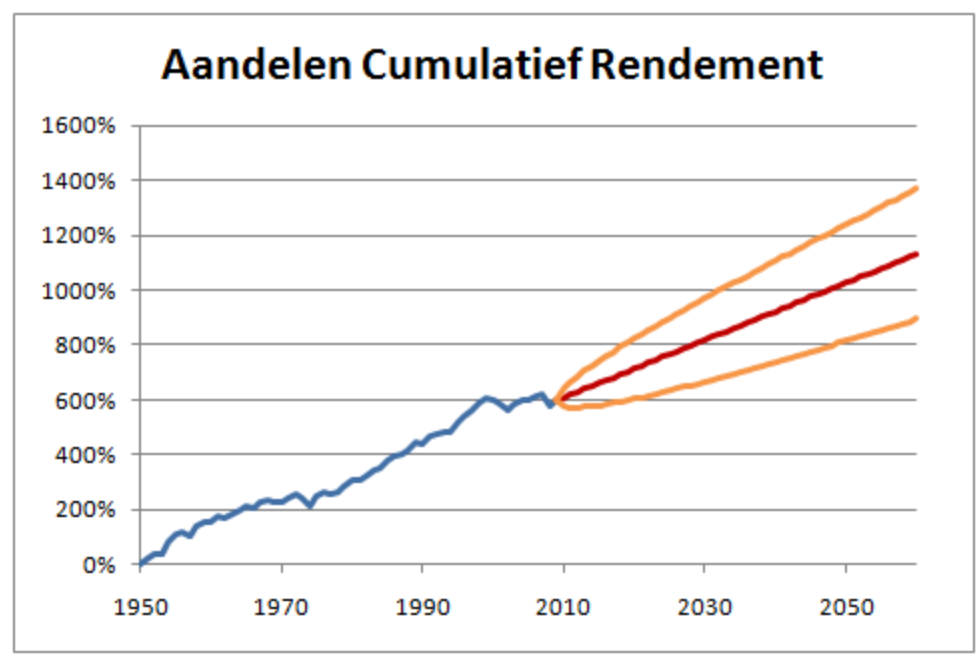

Figuur 4: Projectie voor de periode 2010-2060

Zoals we eerder zagen, is de geschatte trend dat we gemiddeld ongeveer $10 \%$ beleggingsrendement per jaar halen. Als we die trend doortrekken, dan is de projectie voor de komende 50 jaar dat we nog eens $500 \%$ cumulatief rendement behalen. Dus als we in 2010 bij 600\% starten, dan komen we met onze projectie op $1100 \%$ uit in het jaar 2060. Dit wordt weergegeven door de rode lijn in de grafiek. Echter, de rendementen die we jaar-op-jaar behalen fluctueren sterk. Daar houden de projectiemodellen ook rekening mee. We kunnen toekomstige rendementen bepaald niet exact voorspellen, en de onzekerheid in de voorspelling is weergegeven met de oranje "toeter" die rond de rode lijn zit. Dit is, in principe, de basis voor alle projectiemodellen die verzekeraars, pensioenfondsen en de toezichthouders gebruiken.

Er zit echter een lelijke adder onder het gras, en dat is de modelonzekerheid. In dit geval meer specifiek: de trendonzekerheid. De projectie zoals we die het besproken hebben, houdt geen rekening met deze trendonzekerheid. Met ande- 
re woorden, de projectie is "naïef" in de zin dat we (ten onrechte) hebben aangenomen dat we de trend voor de toekomst met absolute zekerheid kennen.

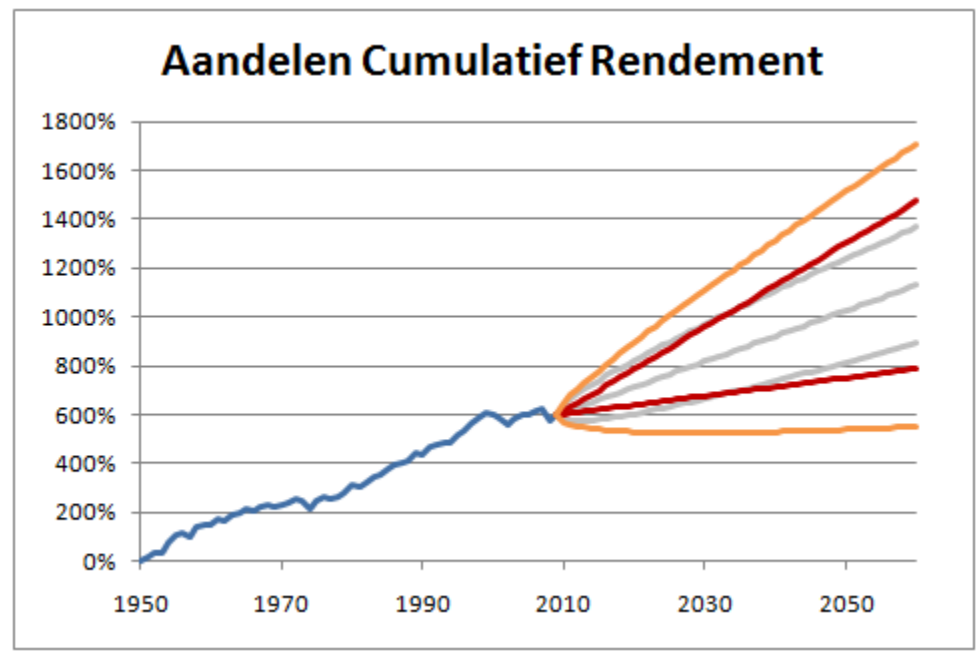

Figuur 5: Projectie met Trendonzekerheid

Wat gebeurt er als we de onzekerheid in de trend wel meenemen in onze projectie? Dit is te zien in Figuur 5. Onze schatting van de trend is zo onzeker, dat we alleen kunnen zeggen dat de trend ergens tussen $3.7 \%$ per jaar en maximaal $17.2 \%$ per jaar ligt. De twee rode lijnen in de grafiek geven de trend voor deze twee uitersten weer. Het schokkende resultaat is, dat tegen de tijd dat we in 2060 zijn aangekomen het effect van alleen al de trendonzekerheid groter is dan de totale spreiding in het "naïeve" model. Als we nu kijken naar het gecombineerde effect van zowel de trendonzekerheid (de rode lijnen) als de onzekerheid in de jaar-op-jaar rendementen (de oranje toeter) dat de totale breedte van de toeter (in vergelijking met het "naïeve" model) meer dan verdubbeld is. 
Dit is in mijn ogen een belangrijke conclusie omdat de meeste projectiemodellen onvoldoende rekening houden met de trendonzekerheid, en dus te optimistisch zijn over de mate van zekerheid in de projecties van toekomstige aandelenrendementen.

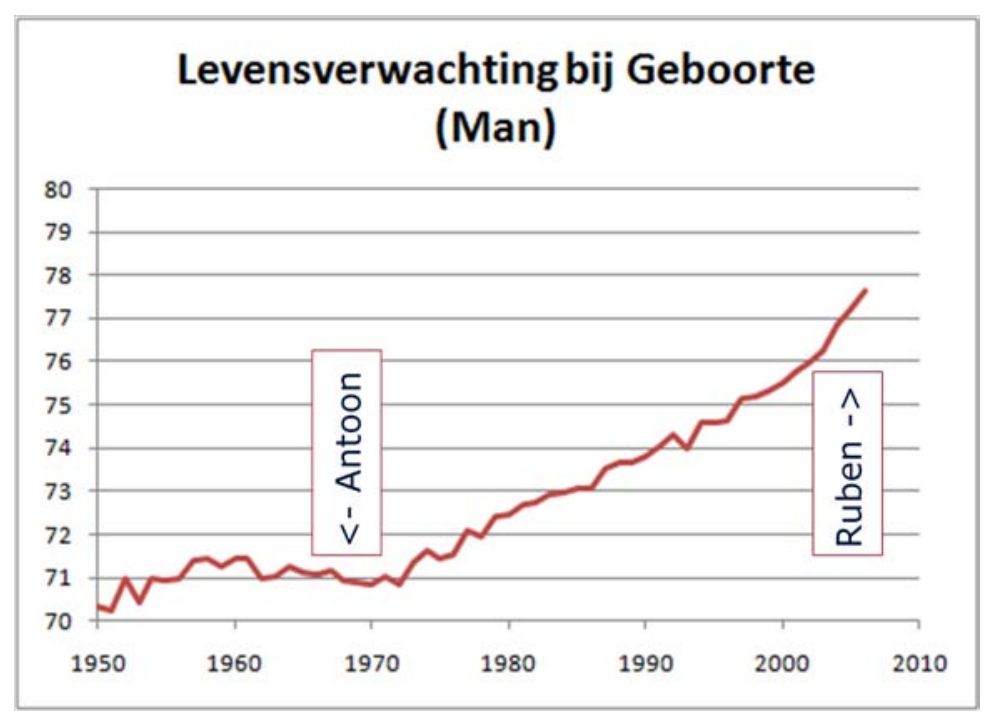

Figuur 6: Ontwikkeling van de Levensverwachting

\subsection{Ontwikkeling van de Levensver- wachting}

Pensioenfondsen en verzekeraars maken niet alleen lange termijn projecties voor aandelenrendementen, maar ook voor de ontwikkeling in de levensverwachting. Zoals u wellicht weet was het enige weken geleden voorpagina nieuws toen het Actuarieel Genootschap bekend maakte dat we nog langer leven dan gedacht. Als gevolg daarvan moeten de pensioenfondsen (die het toch al zo moeilijk hebben) nog 
extra bedragen opzij leggen om de uitkeringen voor de mensen die nog langer blijven leven te kunnen betalen. Ook hier hebben we wederom te maken met het fenomeen van de trendonzekerheid.

In Figuur 6 is weergegeven de ontwikkeling in de levensverwachting bij geboorte voor mannen geboren tussen 1950 en 2006. I kzelf ben geboren in 1968 en had toen een levensverwachting van 71 jaar. Mijn zoon Ruben is geboren in 2004 en hij had toen een levensverwachting van 77 jaar. Dat is een stijging in de levensverwachting van 72 maanden in 36 jaar tijd, dus een gemiddelde stijging van 2 maanden per jaar.

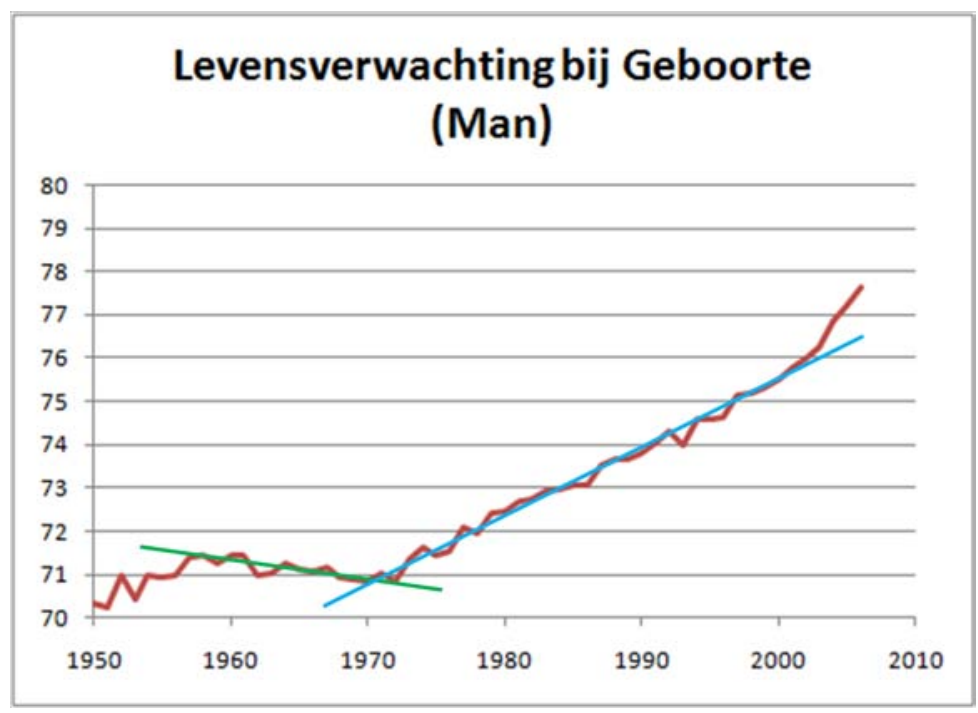

Figuur 7: Wisselende Trends in Levensverwachting

Het patroon dat we zien in de grafiek van de levensverwachting is anders dan bij aandelen. De levensverwachting lijkt zich steeds trendmatig te ontwikkelen, maar de trends wisselen steeds. Ik laat dit zien in Figuur 7. Dit is dezelfde gra- 
fiek als Figuur 6, maar nu heb ik de trendlijnen weergegeven.

Vanaf eind jaren 50 tot begin jaren 70 is er een dalende trend zichtbaar: de levensverwachting voor mannen nam af in die periode. Begin jaren 70 is er een "trendbreuk" zichtbaar: de levensverwachting is gaan stijgen (met ongeveer 2 maanden per jaar). Sinds 2000 lijkt de levensverwachting nog weer sneller te stijgen, en demografen debatteren nu of er sprake is van een nieuwe trendbreuk.

Ik wil mij niet in dit debat mengen, maar ik wil deze grafiek gebruiken om duidelijk te maken dat het (net als bij aandelen) erg lastig is om "de" trend vast te stellen op basis van waarnemingen uit het verleden. Als we projecties willen maken is het, in mijn ogen, belangrijk om de trendonzekerheid expliciet mee te nemen in de projecties.

\subsection{Projectie van Levensverwachting}

In Figuur 8 (op de volgende pagina) laat ik de projectie van de levensverwachting zien voor de periode 2010 tot 2060. De donkerblauwe lijn is de "naïeve" projectie. We nemen de gemiddelde verbetering van de levensverwachting over de periode 1950-2006 (die is 1.8 maanden per jaar) en we trekken die lijn door tot 2060. Op deze manier komen we tot een geprojecteerde levensverwachting van 85.8 jaar voor een man die in 2060 zal worden geboren. Deze projectie komt heel aardig overeen met de meest recente projectie van het Actuarieel Genootschap, die komt op 85.9 jaar uit.

Echter, als we de onzekerheid in de trend expliciet meenemen, dan ziet het plaatje er heel anders uit. De onzekerheid in de trend is wederom zo groot, dat die mogelijk varieert tussen 0.9 maanden verbetering per jaar en 2.8 maanden verbetering per jaar. Deze twee uitersten zijn weergegeven met de lichtblauwe lijnen. Als we dan ook nog eens rekening 
houden met de variatie in de jaar-op-jaar verbeteringen in de levensverwachting dan komen we uit op een totale onzekerheid in de geprojecteerde levensverwachting voor het jaar 2060 die ligt tussen de 77.0 jaar en de 94.6 jaar.

We komen dus wederom tot de conclusie dat de meeste projectiemodellen onvoldoende rekening houden met de trendonzekerheid, en dus te optimistisch zijn over de mate van zekerheid waarmee we de toekomstige levensverwachting kunnen voorspellen.

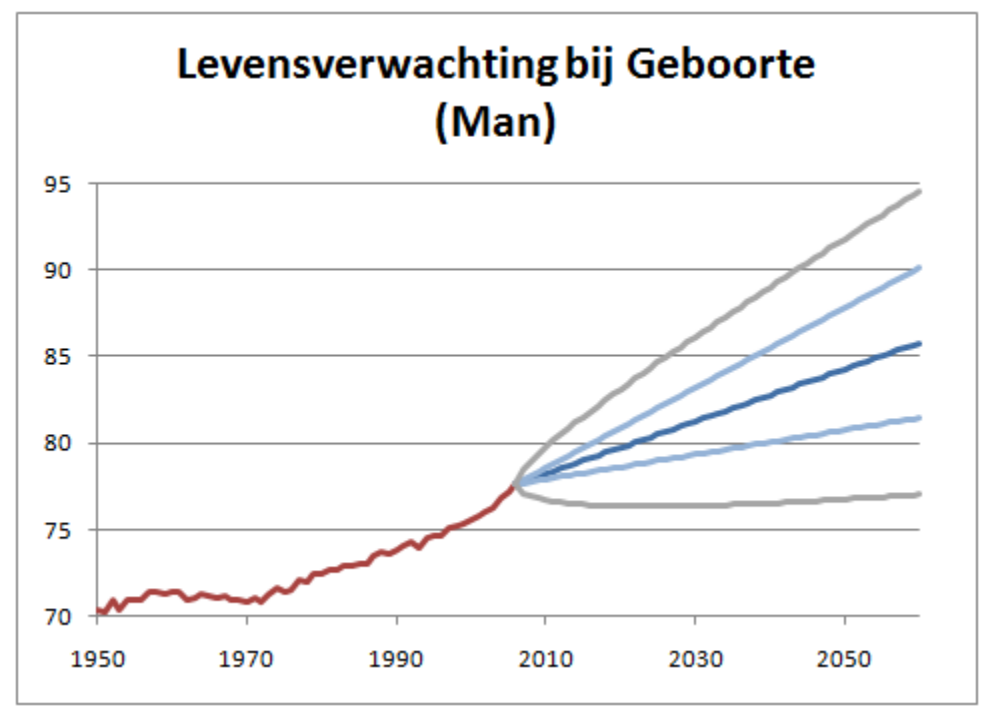

Figuur 8: Projectie van Levensverwachting 


\section{Robuustheid}

Modelonzekerheid heeft niet alleen een grote invloed op het maken van projecties, maar het heeft ook een grote invloed op het bepalen van optimale strategieën.

\subsection{Yathzee}

Om dit te illustreren ga ik weer naar een spel met dobbelstenen. In dit geval het spel Yahtzee. In dit dobbelsteenspel mag je per beurt drie keer gooien met vijf dobbelstenen. Het doel van het spel is om allerlei combinaties te werpen, maar ik wil me richten op één bijzondere beurt in het spel, namelijk CHANCE. Bij de beurt CHANCE hoef je geen enkele combinatie te gooien het doel is alleen maar om in drie worpen zo veel mogelijk punten bij elkaar te gooien. En de vraag is: wat de beste strategie om dit te doen?

Toen ik kind was, speelden we het spel Yahtzee thuis vaak. En als kind gebruikte ik de strategie "zessen vastzetten". Bij elke worp die je gooit leg je de "zessen" opzij. Met de overgebleven dobbelstenen gooi de verder tot je 3 worpen klaar zijn. We kunnen uitrekenen wat de verwachte waarde is van deze strategie. Laten we eerst naar één dobbelsteen kijken. Voor deze dobbelsteen heb ik een kans van $1 / 6$ om in de eerste worp een 6 te gooien. Als die valt, dan zet ik deze dobbelsteen vast en scoor 6 punten voor deze dobbelsteen. Echter ik heb een kans van 5/6 dat er geen 6 valt. In dat geval gooi ik een tweede keer, waarbij ik weer met kans 1/6 een zes gooi die ik dan in de tweede beurt vastzet. Maar met een kans van $(5 / 6) *(5 / 6)$ gooi ik in twee worpen geen zes, en ga door naar de derde en laatste worp, en dan gooi ik gemiddeld 3.5 punten, zoals we in het begin van dit verhaal hebben gezien. Als ik alles nu samen neem, dan heb ik een totale verwachte score (voor één dobbelsteen) van $1 / 6 * 6+$ $5 / 6 *(1 / 6 * 6+5 / 6 * 3.5)=4.26$ punten. Dus voor 5 dobbel- 
stenen heb ik dan een verwachte score van $5 * 4.26=$ 21.32 punten.

Kan het beter? En zo ja, als we een betere strategie vinden hoe weten we dan zeker dat we de best mogelijke, ofwel de optimale, strategie hebben gevonden? Dit zijn heel lastig te beantwoorden vragen, en er is een aparte tak van de wiskunde die zich uitsluitend met dit soort vragen bezig houdt. In het geval in ons Yahtzee-spelletje is er een heel elegante truc om de optimale strategie te vinden. We moeten het probleem niet in de gewone volgorde van worp 1-2-3 analyseren, maar we moeten het probleem van achter naar voren analyseren.

Stel dat we in worp 3 zijn. Dan is het probleem namelijk heel simpel, want er valt niets te kiezen. Je moet gewoon gooien, met verwachte uitkomst 3.5. Nu gaan we één stap terug naar worp 2. Stel ik heb net gegooid, en nu moet ik beslissen of ik de dobbelsteen vastzet of doorga naar worp 3. Ik weet dat als ik doorga naar worp 3, dat ik dan een verwachte uitkomst ben van 3.5. Dus wat is het beste om te doen in worp 2? Als ik een 6, 5 of 4 gooi zet ik die vast (want dat is beter dan de 3.5 van worp 3). Als ik een 1, 2 of 3 dan ga ik wel door naar worp 3 (want dan scoor ik een hoger gemiddelde van 3.5). Voor deze optimale keuze in worp 2 is de verwachte waarde: $1 / 6 *(6+5+4+3.5+3.5+3.5)$ $=4.25$. Nu ga ik terug naar worp 1 . Dan blijkt nu dat als ik een 6 of 5 gooi, dat je die moet vastzetten (want meer dan de verwachte waarde van 4.25 in worp 2), terwijl ik voor een 4 of lager doorga naar worp 2. De verwachte waarde voor de optimale strategie is nu 4.67 per steen, dus 23.33 voor 5 stenen. En dit is beter dan de 21.32 voor de simpele strategie van "zessen vastzetten". 


\subsection{Modelonzekerheid}

De optimale strategie die we net hebben gevonden gaat er van uit dat de dobbelsteen eerlijk is: elke uitkomst heeft dezelfde kans van 1/6. Daar hebben we ook veelvuldig gebruik van gemaakt in onze berekeningen.

Stel nu dat we onzeker zijn over de kansen. (We spelen Yahtzee via een website van een mogelijk louche internetondernemer die snel rijk wil worden.) We gaan dus wederom naar modelonzekerheid kijken. Hoe kunnen we nu een "optimale" strategie vinden. Dat ligt een beetje moeilijk. Want wat "optimaal" is kunnen we alleen maar definiëren in de context van een gegeven model. Als we nu onzeker zijn over het juiste model, dan is "de optimale" strategie ook niet meer eenduidig vast te stellen. Dit is een belangrijk inzicht: "optimaal" is een relatief begrip dat sterk wordt bepaald door de model-context.

Wat moeten we nu doen als we niet meer "de" optimale strategie kunnen bepalen. Een veel gebruikt alternatief is om te kijken naar robuuste strategieën. Het begrip robuustheid komt, zoals eerder aangestipt, uit de technische wetenschappen (het bouwen van kerncentrales, en zo). Bij een robuuste strategie kijken we naar de best mogelijke strategie voor het slechtst mogelijke model. Voor alle andere mogelijke modellen (die minder slecht zijn) doen we het dan in ieder geval beter, maar we vinden dan niet meer de "optimale" strategie voor elk model. In het Engels kunnen we de robuuste strategie karakteriseren als: "Prepare for the worst, hope for the best".

In ons dobbelsteenmodel kunnen we modelonzekerheid introduceren door de kansen op elke uitkomst onzeker te maken. In Figuur 9 laten we de robuuste strategieën zijn bij toenemende modelonzekerheid van de kansen van de dobbelsteen. De eerste rij geeft de situatie weer dat er geen 
modelonzekerheid is, en dat we met een eerlijke dobbelsteen spelen met kansen $16.7 \%$ voor elke uitkomst. De "optimale" strategie is dan wat er we eerder hebben uitgerekend: in de eerste worp zessen en vijven vastzetten, in de tweede worp zessen, vijven en vieren. Dit hebben we schematisch weergegeven met "6 5 / 65 4". Naarmate we naar beneden zakken in de tabel worden we steeds onzekerder over de juiste kansen.

\begin{tabular}{|c|c|}
\hline Kans op 6 & \\
\hline $16.7 \%$ & $65 / 654$ \\
\hline $15.0 \%$ & $65 / 654$ \\
\hline $13.3 \%$ & $654 / 654$ \\
\hline $11.7 \%$ & $654 / 6543$ \\
\hline $10.0 \%$ & $654 / 6543$ \\
\hline $8.3 \%$ & $654 / 6543$ \\
\hline $6.7 \%$ & $6543 / 6543$ \\
\hline $5.0 \%$ & $6543 / 65432$ \\
\hline $3.3 \%$ & $65432 / 65432$ \\
\hline $1.7 \%$ & $65432 / 65432$ \\
\hline
\end{tabular}

\section{Figuur 9: Robuuste Strategieën bij} toenemende modelonzekerheid

In de middelste rij van de tabel zijn we zo onzeker over de kansen dat we denken dat ze ergens tussen de $10 \%$ en de $28 \%$ liggen. We berekenen dan eerst de slechtst mogelijke verdeling van de kansen (lage kansen op hoge uitkomsten, hoge kansen op de lage uitkomsten) en voor dit slechtst mogelijke model bepalen we dan de beste strategie. We zien dat de robuuste strategie anders is dan de "optimale" strategie. Omdat het onwaarschijnlijker wordt om hoge ogen te gooien, gaan we eerder dobbelstenen vastzetten. Voor de $10 \%$-rij is de robuuste strategie "6 54 / 654 3". In de onderste rij zijn we zo pessimistisch geworden voor het slechtste model (91.7\% kans op een " 1 " en slechts $1.7 \%$ kans op 
de andere uitkomsten) dat de optimale strategie elke kans aangrijpt om een uitkomst hoger dan een "1" gelijk maar vast te zetten.

Het is natuurlijk prachtig om deze strategieën als "robuust" aan te prijzen, maar we zijn we niet veel te pessimistisch door maar steeds van het slechtst mogelijke model uit te gaan? Dat kunnen we onderzoeken door twee situaties met elkaar te vergelijken. Ten eerste kunnen we kijken naar het verlies van de "naïef optimale" strategie als je onverhoopt toch met een oneerlijke dobbelsteen speelt. Ten tweede kun je kijken naar het verlies dat je lijdt als je met de robuuste strategie met een eerlijke dobbelsteen speelt.

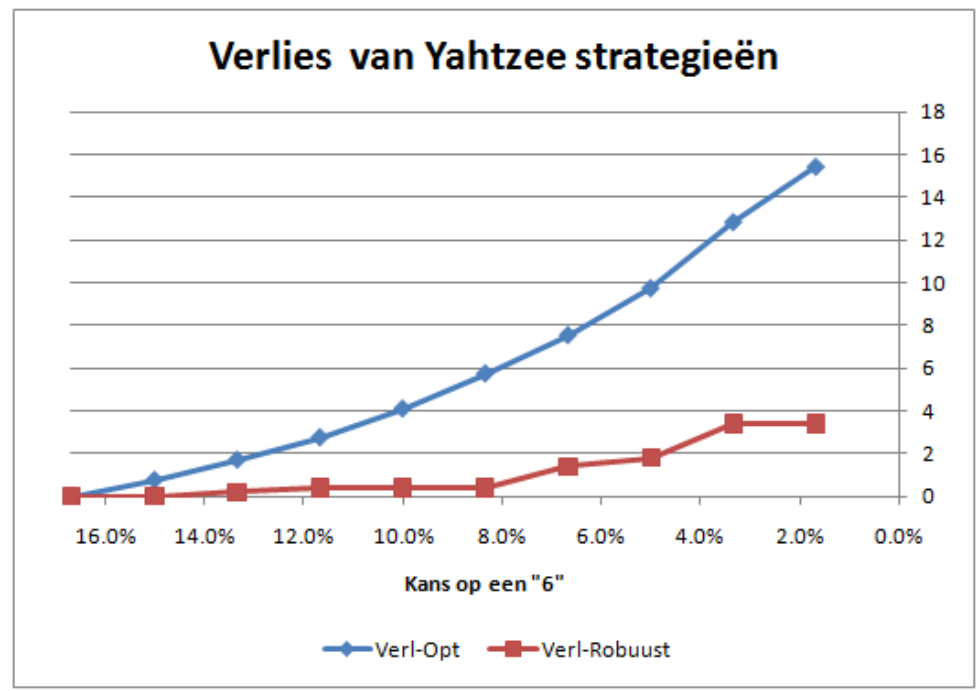

Figuur 10: Verlies van Optimale en Robuuste Strategieën

In Figuur 10 zien we twee lijnen. De blauwe lijn geeft het verlies van de "naïef" optimale strategie weer bij een steeds oneerlijker dobbelsteen (weergegeven door een steeds lage- 
re kans op een "6"). De bruine lijn geeft het verlies weer van de robuuste strategie ten opzichte van de optimale strategie als de dobbelsteen wel eerlijk is. Aan de linkerkant van de grafiek is er geen modelonzekerheid en is de robuuste strategie gelijk aan de optimale strategie en zijn de verliezen 0 . Als we naar rechts bewegen (de dobbelsteen wordt steeds oneerlijker) dan zien we de verliezen van de optimale strategie veel sneller oplopen dan de verliezen van de robuuste strategie.

Dit is een illustratie van een tweede belangrijke conclusie: het verlies van een "naïef optimale" strategie bij een slechte modeluitkomst is veel groter dan het verlies van de robuuste strategie in het "meest waarschijnlijke" model.

Als we dus te maken hebben met modelonzekerheid, dan heeft dat niet alleen een effect op de projecties voor de toekomst. Maar als we een "optimaal" beleggingsbeleid en premiebeleid vaststellen zonder rekening te houden met modelonzekerheid, dan is de kans erg groot dat we keer op keer forse tegenvallers moeten melden als we economische tegenwind hebben.

\section{Waardering}

Laten we nu eens kijken of we de methoden van modelonzekerheid en robuuste strategieën kunnen toepassen voor pensioenfondsen. De laatste tijd zitten de pensioenfondsen behoorlijk in de hoek waar de klappen vallen. Een maand geleden schreef minister Donner zijn brief waarin hij aankondigde dat 14 pensioenfondsen een zo ernstige onderdekking hebben dat ze verplicht worden om de opgebouwde rechten van de deelnemers te korten. Een paar weken later kwam het Actuarieel Genootschap met de nieuwe projecties 
voor de levensverwachting waaruit bleek dat we nog ouder worden dan we al dachten. Dit nieuws kwam nog een keer boven op de extreem lage rente en de tegenvallende beursresultaten die we nu meemaken.

Mijn stelling is, dat deze aanhoudende stroom van slecht nieuws berichten in belangrijke mate valt terug te voeren op het veronachtzamen van modelonzekerheid. I $\mathrm{k}$ wil zeker niet beweren dat de modellen die tot nu toe zijn gehanteerd te optimistisch zijn geweest. Ik denk dat iedereen te goeder trouw is geweest en heeft geprobeerd om zo goed mogelijk de economische werkelijkheid te modelleren. Maar door geen rekening te houden met modelonzekerheid, is de sector toch te optimistisch gebleken, omdat men te veel heeft vertrouwd op de geprojecteerde uitkomsten van "naïef optimale" beleggingsstrategieën en daarmee samenhangend premiebeleid.

Wat ik in het laatste deel van mijn betoog wil doen, is kijken welke nieuwe inzichten we krijgen als we naar een pensioenfonds kijken als we wel de modelonzekerheid meenemen. De modellen die door pensioenfondsen worden gebruikt zijn buitengewoon geavanceerd en complex. Het is dus ondoenlijk om hier in vijf minuten een compleet pensioenfondsmodel met $u$ door te nemen. Wat is dus zal doen is kijken naar een extreem vereenvoudigd model. Op deze manier krijgt $u$ hopelijk toch een idee van wat de impact is van modelonzekerheid op een pensioenfonds.

Het model waar ik mee ga werken kent slechts twee onzekere elementen: het beleggingsrendement en de levensverwachting. I $\mathrm{k}$ beschouw een fonds dat voor de komende 40 jaar rechten wenst op te bouwen voor een deelnemer. $\mathrm{Er}$ is vandaag een bedrag in kas gestort, dat het fonds de komende 40 jaar zal beleggen tegen een vast percentage in aandelen en het resterende gedeelte wordt belegd in risicovrije 
obligaties die een gegarandeerd rendement van $4 \%$ opleveren. $\mathrm{Na} 40$ jaar beleggen is het bedrag aangegroeid. Afhankelijk van hoeveel er in aandelen is belegd, is het eindbedrag onzekerder, maar gemiddeld genomen behalen we wel een hoger rendement als we meer in aandelen beleggen. Dit is in een notendop de risico/rendement-afweging waar elke belegger mee worstelt. Na 40 jaar gaat de deelnemer met pensioen en krijgt dan levenslang een maandelijks bedrag uitgekeerd. Echter, deze levenslange uitkering is een onzekere post, want het pensioenfonds is onzeker over de resterende levensduur van de deelnemer. Het pensioenfonds stelt zich tot doel om de verwachte dekkingsgraad over 40 jaar naar verwachting zo hoog mogelijk te krijgen door een "optimale" beleggingsmix te kiezen.

Ik wil nogmaals benadrukken dat dit een extreem vereenvoudigde weergave is van de werkelijkheid, dit model geeft slechts een paar elementen weer van het enorm complexe vraagstuk waar de pensioensector mee worstelt.

\subsection{Slechtste Model}

Aan de twee onzekere elementen (beleggingsrendement en levensverwachting) voegen we nu expliciet de trendonzekerheid toe die we eerder hebben besproken. Wat is nu het "robuuste" beleggingsbeleid voor ons modelfonds? Dit blijkt af te hangen van de initiële dekkingsgraad.

In Figuur 11 zien we een heleboel getallen staan. Ik zal proberen $u$ door deze brij van getallen heen te leiden, en te laten zien wat voor verborgen schatten hier te vinden zijn.

In de eerste kolom zien we 4 blokjes met daarin "A0" en steeds een percentage. Dit is de initiële dekkingsgraad. De dekkingsgraad geeft de verhouding weer van de waarde van de beleggingen (in dit geval het bedrag dat het fonds net in kas gestort heeft gekregen) en de waarde van de verplich- 
tingen (in dit geval de levenslange uitkering). Een pensioenfonds wordt geacht een dekkingsgraad te hebben van tenminste $105 \%$. In de bovenste rij is het fonds rijk met een dekkingsgraad van $185 \%$. In de onderste rij heeft het fonds een slechte dekkingsgraad hebben van maar $74 \%$ en kan elk moment een boze brief van minister Donner in de bus vallen.

\begin{tabular}{|c|c|c|c|c|c|c|c|}
\hline & \%-beleg.mix & $0 \%$ & $5 \%$ & $10 \%$ & $15 \%$ & $20 \%$ & $25 \%$ \\
\hline $185 \%$ & Aandelen & $0.0 \%$ & $-5.8 \%$ & $-6.4 \%$ & $-6.6 \%$ & $-6.7 \%$ & $-6.7 \%$ \\
\hline A0 & Levensverw. & 1.49 & 0.78 & 0.46 & 0.32 & 0.25 & 0.20 \\
\hline 5.00 & E(surpl) & 9.292 & 10.572 & 10.694 & 10.645 & 10.544 & 10.422 \\
\hline $130 \%$ & Aandelen & $0.0 \%$ & $-5.2 \%$ & $-6.2 \%$ & $-6.5 \%$ & $-6.6 \%$ & $-6.6 \%$ \\
\hline A0 & Levensverw. & 1.49 & 0.96 & 0.61 & 0.44 & 0.35 & 0.28 \\
\hline 3.50 & E(surpl) & 1.863 & 3.002 & 3.231 & 3.263 & 3.231 & 3.170 \\
\hline $102 \%$ & Aandelen & $0.0 \%$ & $-4.7 \%$ & $-5.9 \%$ & $-6.3 \%$ & $-6.5 \%$ & $-6.6 \%$ \\
\hline A0 & Levensverw. & 1.49 & 1.08 & 0.72 & 0.54 & 0.43 & 0.35 \\
\hline 2.75 & $\mathrm{E}$ (surpl) & -1.852 & -0.825 & -0.541 & -0.460 & -0.453 & -0.480 \\
\hline $74 \%$ & Aandelen & $0.0 \%$ & $-3.9 \%$ & $-5.4 \%$ & $-6.0 \%$ & $-6.3 \%$ & $-6.4 \%$ \\
\hline A0 & Levensverw. & 1.49 & 1.21 & 0.88 & 0.68 & 0.55 & 0.46 \\
\hline 2.00 & E(surpl) & -5.567 & -4.700 & -4.366 & -4.231 & -4.178 & -4.165 \\
\hline
\end{tabular}

\section{Figuur 11: Robuust Beleggingsbeleid}

In de volgende kolommen zien we wat er gebeurt met het pensioenfonds als ze de komende 40 jaar een steeds groter percentage in aandelen beleggen. Laten we beginnen bij het rijke fonds met $185 \%$ dekkingsgraad. Onder het kopje $0 \%$ staan 3 getallen. Het onderste getal (van de drie) is de verwachte waarde van het surplus van het fonds. Deze waarde probeert het fonds zo groot mogelijk te krijgen door het kiezen van de beste beleggingsmix. Echter, de verwachting wordt uitgerekend op een robuuste manier, dus onder het slechtst denkbare model. En dat is waar de twee getallen erboven voor zijn: deze geven aan welke afslag of opslag voor de trend bij aandelen en levensverwachting leiden tot het slechtst mogelijke model bij deze beleggingsmix. 
Voor een beleggingsmix van $0 \%$ in aandelen hebben we helemaal niets te maken met onzekerheden in aandelen, en het slechtst mogelijke model is daarom om uitgegaan van de snelst mogelijke stijging van de levensverwachting. In dit geval een opslag van 1.49 maand bovenop de trend van 1.8 maanden per jaar.

Als we nu naar de volgende kolom kijken, dan zien we de uitkomsten voor een beleggingsbeleid met $5 \%$ belegd in aandelen. Nu zien we iets interessants: het slechtste model is nu een ander model! Omdat we een gedeelte in aandelen beleggen, worden we afhankelijk van de modelaannamen die we maken voor de toekomstige aandelenrendementen. Het slechtst mogelijke model gaat nu uit van een afslag van $5.8 \%$ op de trend van $10.4 \%$ voor aandelen, en een opslag van 0.78 maanden bovenop de sterftetrend van 1.8 maanden per jaar. Hier zien we één van de mechanismen waarom robuuste strategieën daadwerkelijk "robuust" zijn. Door steeds uit te gaan van het slechtst denkbare model, worden op een effectieve manier te optimistische toekomstverwachtingen de kop ingedrukt. Dus op het moment dat we denken een beter rendement te kunnen behalen door meer in aandelen te beleggen, reageert het slechtste model hier onmiddellijk op door een grotere afslag op de trend voor aandelen in rekening te brengen.

We zien dit mechanisme ook duidelijk aan het werk aan de onderkant van de tabel, dus bij het fonds met de dekkingsgraad van $74 \%$. Bij een dergelijk fonds is de situatie al slecht, en een onverwachte stijging van de levensverwachting hakt er dan extra hard in. (Zoals de pensioenfondsen nu aan den lijve ondervinden). Als dit arme fonds $0 \%$ in aandelen belegt, dan is het slechtste model hetzelfde als bij het rijke fonds: geen afslag bij aandelen, en een opslag van 1.49 maand bovenop de trend in de levensverwachting. 
Als nu dit arme fonds kijkt naar een beleggingsmix met $5 \%$ aandelen, dan gaat het slechtste model uit van een afslag van $3.9 \%$ van de aandelen trend, en een opslag van 1.21 maand voor de trend in de levensverwachting. Het slechtste model blijft dus meer nadruk leggen op een onverwachte stijging in de levensverwachting, dan op een tegenvaller in het beleggingsrendement, in vergelijking met het slechtste model voor het rijke fonds.

\subsection{Robuust Beleid}

Zoals gezegd, bekijken we voor de verschillende fondsen (rijk en arm) wat het verwachte surplus is (steeds onder het slechtste model) voor een groeiend percentage belegd in aandelen stijgen van $0 \%$ tot $25 \%$. Het "robuuste" punt is voor ieder fonds weergegeven met een gekleurd vakje.

Voor het rijke fonds (met een dekkingsgraad van 185\%) is het robuuste beleid om $10 \%$ in aandelen te beleggen. Voor het arme fonds is het robuuste beleid om $25 \%$ in aandelen te beleggen. Omdat het model dat ik hanteer extreem vereenvoudigd is, wil ik zeker niet beweren dat deze percentages de "juiste" manier zijn om te beleggen voor echte pensioenfondsen.

Ik wil naar een ander punt toe. Het blijkt dat de waarde waarin het beste verwachte surplus wordt gevonden, voor alle fondsen overeen komt met hetzelfde slechtste model. In elk gekleurd vakje gaat het slechtste model uit van een afslag van $6.4 \%$ op de aandelentrend, en een opslag van 0.46 maanden op de trend in de levensverwachting. Dus het "optimaal slechtste" model blijkt uniek gedefinieerd te zijn, ongeacht hoe rijk of hoe arm het pensioenfonds is.

Dit opmerkelijke resultaat blijkt algemeen te gelden als we kijken naar beleggingsproblemen waarbij we te maken heb- 
ben met trendonzekerheid, en we te maken hebben met financiële en niet-financiële risico's.

\subsection{Robuuste Waardering}

Alsof dit nog niet genoeg is; er is nog meer opmerkelijks aan de hand. De afslag van $6.4 \%$ op de aandelentrend is heel bijzonder: als we beginnen met de geschatte trend van $10.4 \%$ en we trekken er $6.4 \%$ vanaf dan blijft er $4 \%$ over, en dat is in ons model het risicovrije rendement. Ook dit resultaat blijkt algemeen te gelden. Als we kijken naar beleggingsproblemen waarbij we te maken hebben met trendonzekerheid, en we te maken hebben met financiële en niet-financiële risico's, dan worden in het "optimaal slechtste" model alle financiële risico's gelijkgeschakeld door de rendementen op het risicovrije rendement te stellen.

Aan de andere kant wordt voor de niet-financiële risico's uitgegaan van opslag op de trend, zodanig dat men tot een voorzichtige (of "prudente") projectie van de niet-financiële risico's komt. Dit is een methodiek die actuarissen al zeer lang toepassen, zij het dat de afslagen meer "op gevoel" werden vastgesteld dan op basis van harde theorie.

Modellen waarin alle financiële risico's over één kam worden geschoren worden ook wel "markt-consistente" modellen genoemd. Deze klasse van markt-consistente modellen is de laatste jaren heel belangrijk geworden voor het toezicht op verzekeraars en pensioenfondsen. Voor pensioenfondsen heeft dit geleid tot de "actuele waarde" methodiek waarbij de verplichtingen contant worden gemaakt tegen de risicovrije rente, ongeacht het verwachte rendement van de beleggingen die daar tegenover staan.

Omdat de rente nu erg laag is, zuchten en steunen de pensioenfondsen onder deze waarderingsmethodiek. De roep 
om aanpassing van de methode is de laatste maanden steeds luider geworden.

\subsection{I deeën voor Verder Onderzoek}

Ik denk dat pensioenfondsen voor een deel terecht klagen. De huidige rekenregels voor de "actuele waarde" zijn te simpel. Die gaan uit van een hypothetische markt voor pensioenverplichtingen, en de waarde die de pensioenverplichtingen op die hypothetische markt dan zouden hebben.

Aan de andere kant vind ik dat de pensioenfondsen de oplossing in de verkeerde richting zoeken. De oplossing die pensioenfondsen nu aandragen komt in grote lijnen neer op: de rente is nu extreem laag, we weten de we op lange termijn veel betere beleggingsrendementen zullen halen, dus laten we nu alvast maar met een hogere rente rekenen. $U$ zult begrijpen dat ik dit soort oplossingen te zwaar vind leunen op het doortrekken van trends uit het verleden, en dat er op deze manier te weinig rekening wordt gehouden met de modelonzekerheid op lange termijn.

Ik hoop dat we door middel van de technieken van modelonzekerheid en robuustheid die ik hier heb geschetst, een stap verder kunnen komen in het oplossen van dit probleem met grote maatschappelijke relevantie. Een aantal van de onderzoeksvragen waar ik mij de komende tijd mee bezig wil gaan houden zijn:

- Hoe nemen we de onzekerheid in het langlevenrisico mee in de waardering?

- Hoe moeten we zeer lang lopende betalingsverplichtingen waarderen als er geen beleggingen te vinden zijn met een vergelijkbare looptijd?

- Hoe kunnen we extreem grote pensioenportefeuilles waarderen, waarvan de omvang vele malen groter is dan het handelsvolume van de financiële markten? 
- Wat is de waarde van beleggingen die weinig worden verhandeld in financiële markten?

Door middel van dit soort onderzoeksvragen hoop ik de komende jaren een steentje bij te kunnen dragen aan zowel de wetenschappelijke als maatschappelijke discussies in dit fascinerende vakgebied.

\section{Woord van Dank}

Aan het eind van mijn rede wil ik graag een paar woorden van dank uitspreken. Allereerst aan mijn promotor en "wetenschappelijke vader" Ton Vorst. Bij hem heb ik (eerst als student-assistent, en later als promovendus) het wetenschappelijke ambacht geleerd. Na mijn studie heb ik 14 jaar in het bedrijfsleven gewerkt: eerst op de dealingroom bij ABN-Amro, later als risk manager bij ING. Ik wil mijn voormalige collega's danken voor de schat aan praktijkervaring die ik in die jaren heb opgedaan. Drie jaar geleden besloot ik om $100 \%$ over te stappen naar de wetenschap. Zowel mijn oud-collega's van de Universiteit van Amsterdam als mijn nieuwe collega's aan de Universiteit Maastricht van de vakgroepen Kwantitatieve Economie en Finance hebben mij steeds warm verwelkomd in hun midden, en mij de vrijheid gegeven om mijn ideeën uit te voeren. Naast het doen van onderzoek, is het geven van colleges ook iets wat ik met groot plezier doe. Met name het contact met studenten blijft steeds weer inspireren. Last, but not least, wil ik graag mijn vrouw Chantal en mijn kinderen Rebecca en Ruben bedanken voor hun voortdurende steun en liefde.

I k heb gezegd. 